\title{
Language and Intercultural Communicative Competence in the Professional Training of Business Specialists
}

\author{
Albina Bilyalova \\ Department of Philology \\ Kazan Federal University \\ Naberezhnye Chelny, Russia \\ abill71@mail.ru \\ Aigul Nurullina \\ Department of Philology \\ Kazan Federal University \\ Naberezhnye Chelny, Russia \\ aigulnur1988@mail.ru
}

\author{
Dinara Khairullina \\ Department of Philology \\ Kazan Federal University \\ Naberezhnye Chelny, Russia \\ dinara0406@mail.ru \\ Nadezhda Ziganshina \\ Department of Foreign Languages \\ Almetyevsk State Oil Institute \\ Almetyevsk, Russia \\ zinale@ rambler.ru
}

\author{
Elena Mochelevskaya \\ Department of Economics and Engineering \\ Kazan National Research Technical University named after A.N. Tupolev - KAI \\ Almetyevsk, Russia \\ x.alena@mail.ru
}

\begin{abstract}
The modern development of the world economy in the context of globalization involves the expansion of company activity from the regional to the international level. Such expansion definitely contributes to a number of economic advantages. However, this inevitably causes a number of problems, the main of which are the language barrier and misunderstanding between cultures, which can lead not only to financial losses, but also to problems with reputation. This fact determines the need for specialists with intercultural communication skills and knowledge of foreign languages. Thus, the article discusses the importance of language and intercultural competence of future specialists in international business. The article considers the essence and content of the phenomenon of intercultural competence of a specialist in the field of economics and business, defines the role and importance of studying the characteristics of business cultures of different countries of the world for successful intercultural interaction. It is concluded that language and intercultural competence is becoming more and more popular today, since in the conditions of integration and globalization the success of a specialist's activity depends on it.
\end{abstract}

Keywords: intercultural communication, language competence, international business, language barrier

\section{INTRODUCTION}

Globalization leads to worldwide integration in various areas of human life. A logical consequence of such a powerful process is the interpenetration of cultures, which forces a person to reconsider their attitude to the study of foreign languages: if previously the knowledge of the language and culture of another country was considered sufficient, then now we are talking about the formation of intercultural competence of a specialist. The growing number of international corporations as the dominant form of business organization stimulates an increased interest in intercultural communication as a soft skill which is necessary for a favorable atmosphere in business offices, for the success of negotiations and everyday business activities.

Globalization involves the extension of a global labor market, where such specialists are needed who can effectively communicate with representatives of other cultures in any situation of professional interaction. The complexity of this communication lies in numerous cultural barriers that can lead not only to misunderstanding, but also to disappointment in the opponent (negotiating partner), and even to the development of the conflict. This is because the interlocutor's 
- $\quad$ scientific methods of theoretical research: analysis of domestic and foreign methodological literature on the research problem;

- methods of empirical research: testing, questioning, studying the products of students' activities, pedagogical experiment, qualitative and quantitative analysis of its results.

\section{RESULTS}

In our opinion, a foreign language is one of the disciplines that, in modern conditions, acquires a new meaning and becomes a very important link in the development of the necessary communicative and other social skills of future e business professionals. In the course of the English study, we have developed a model of comparing business cultures for the development ICC, which includes three stages: informative, value-oriented, and productive-evaluative. This paper presents the informative stage of the process of development of the ICC.

The informative stage is focused on the development of students' ideas about the information space of intercultural communication, knowledge of the characteristics of various cultures, their traditions, customs, cultural values, the development of the ability to integrate Russian spirituality into another culture through a foreign language. It also provides an understanding of the differences in ethical requirements for communication, rules of conduct, lifestyle. The informative stage stimulates the development of students' abilities to critically interpret the information received and embed it in their own picture of the world. It contributes to an opportunity to get ideas not only about language and culture, but also about the process of intercultural communication itself. As part of the informative stage, we have developed an algorithm for comparing two business cultures using the example of comparing cultures of Russia and the UK according to certain criteria: general information, the role of a manager, approach to changes, approach to time, making decisions, teamwork, communication and negotiation styles.

Let's consider in detail the criteria for comparing two business cultures.

\section{A. General information}

In the UK, you must treat all people for intercultural communication with respect and reverence and not wasting anyone's time. It must be remembered that the British are inclined to sarcasm. Managers often make decisions collectively, involving subordinates colleagues. That is, the style of communication within companies has the features of a democratic one. In Russia, a characteristic feature is that the main business style in companies is official. In other words, in business it is better to use a formal approach and keep in mind that in intercultural communication Russians pay attention to the hierarchy and status of a person in a company.

\section{B. The role of the manager}

Intercultural communication with representatives of the UK will be more effective if you remember that managers

In the paper the research methods were used: 
to deal with those whom they trust, so they spend a lot of time developing relations. It should also be remembered that joint problem solving is the main function of negotiations. The implementation of this function depends on the degree of interest of the participants in the search for a mutually acceptable solution.

The proposed model of comparing business cultures also includes foreign language communication analysis methodology, Web quest technique and the methodology of creating a portfolio, the methodology for assessment the components of intercultural competence included:

\section{- $\quad$ Foreign language communication analysis methodology}

More complex is the methodology for analyzing communication in a foreign language recorded on audio or video media. Similar examples of communication should demonstrate both the interaction of representatives of foreign culture among themselves, and the interaction of representatives of different cultures.

In general, this gives students an additional information base in several directions at once. Firstly, communication as an integral part of people's lives characterizes the whole culture, that is, such examples will become an important source of socio-cultural knowledge for students. Secondly, this method will help students to create in their minds unique patterns of behavior of a particular culture, which can later develop into behavioral reactions. Thirdly, thematically selected video and audio materials can help students expand their knowledge of the characteristics of doing business in different countries. Thus, by studying the content of examples of professional communication, students receive additional information that covers such areas of business communication as the range of topics discussed, standard constructions of behavior, options for different interpretations of certain expressions, and ways to avoid and eliminate conflicts. At the end of the work, students can demonstrate their knowledge in the form of a written report or in a collective discussion.

- Web quest technique

Another methodology for comparing business cultures in foreign language classes at the university is Web quest technique. It is a focused study of the material provided in the Internet. The structure of the webquest includes six stages:

- the introduction of the teacher to interest students, basic information about the topic;

- statement by the teacher of a task that should be feasible and interesting;

- familiarization of students with the sources of information that are necessary to perform a specific task;

- description by the teacher of the directions in which students should work in order to fulfill the task, as well as some recommendations of the teacher on the fulfillment of the information received; 
TABLE I. RESULTS OF THE EXPERIMENT

\author{
assessing the assignment;
}

- the students' making up the conclusion, which should systematize their knowledge.

Webquest is designed to enable students to play an active role in obtaining knowledge. This method involves not only the development of the ability to search for information, but also the ability of students to critically interpret and synthesize information, to solve the problems posed in the task with its help.

\section{- The methodology of creating a portfolio}

The methodology of creating a portfolio by students is one of the most effective in terms of the ability to assess the knowledge, skills and competence of students, on the one hand, and in terms of creating conditions for independent creative work of students, on the other. There are special programs for creating electronic student portfolios (for example, Mahara), which allow students not only to create separate documents, edit them, but also independently evaluate their compliance with modern standards and requirements [23]. That is, students can not only prepare assignments for university studies, but also independently assess the degree of their own willingness to work in any company, as well as the level of their own competitiveness in the labor market.

The proposed model of comparing business cultures was used in business English practical classes at the university. The effectiveness of the methodology for the development of intercultural communicative competence of students of the Economics Department was tested in the course of experimental work. In total, 35 students participated in the experiment. In general, the work carried out allowed the development of practical skills of intercultural communication. It is proved by the diagnostics of the development of components of intercultural competence of students of the Economics Department studying according to the developed methodology (35 people). The components of intercultural competence were presented in the form of low, medium, high levels.

- The methodology for assessment the components of intercultural competence includes:

a) test on vocabulary;

b) essay "Characteristics of the economy of an Englishspeaking country (USA, Great Britain, Australia);

c) the questionnaire "What do I know about the USA, Great Britain, Australia?"

d) an oral survey (dialogue in situations of intercultural communication);

e) interview "Your attitude to the culture, traditions of the USA, Great Britain, Australia".

Table I summarizes the results of this study (data are given in absolute numbers).

\begin{tabular}{|l|l|l|l|l|l|l|l|}
\hline \multirow{2}{*}{$\begin{array}{c}\text { Components } \\
\text { intercultural } \\
\text { competence }\end{array}$} & \multicolumn{2}{|c|}{ Low level } & \multicolumn{2}{c|}{ Average level } & \multicolumn{2}{c|}{ High level } \\
\cline { 2 - 7 } & before & after & before & after & before & after \\
\hline $\begin{array}{l}\text { Cognitive } \\
\text { (awareness) }\end{array}$ & 20 & 11 & 10 & 14 & 5 & 10 \\
\hline $\begin{array}{l}\text { Pragmatic } \\
\text { (skills of } \\
\text { intercultural } \\
\text { communication) }\end{array}$ & 22 & 12 & 8 & 12 & 5 & 11 \\
\hline $\begin{array}{l}\text { Motivational } \\
\text { (respect, interest } \\
\text { in the culture of } \\
\text { the English- } \\
\text { speaking } \\
\text { country) }\end{array}$ & 8 & 0 & 15 & 17 & 12 & 18 \\
\hline $\begin{array}{l}\text { Information and } \\
\text { practical } \\
\text { (mastering of } \\
\text { skills of work in } \\
\text { English- } \\
\text { language search } \\
\text { engines) }\end{array}$ & 15 & 8 & 2 & 9 & 18 & 18 \\
\hline
\end{tabular}

These data indicate that during the experimental training the indicators of cognitive, pragmatic, information and practical components of intercultural competence have improved most markedly. It is important to pay attention that the motivational component was initially developed, which is explained by the socially significant personal qualities of students (openness, tolerance).

The proposed methods of comparing business cultures of different countries of the world according to a certain algorithm and analysis of communication in a foreign language can be used in practical classes in a foreign language and business foreign language at the University.

\section{DISCUSSIONS}

Intercultural competence is an integral part of communicative competence. For this reason, it is advisable to refer to the concept of communicative competence. Communicative competence (CC) is one of the basic categories of modern theory and practice of teaching foreign languages and, in particular, English as a foreign language. In the scientific literature there are many definitions of the concept of (CC). There are different approaches to the structural analysis of this phenomena. The first linguist who distinguished difference between language as a system "langue " and "speech parole" was Ferdinand de Saussure. According to F. Saussure, under the system only the language that can be learned was meant, while speech activity is already the product of a specific speaker. Later, the definition of the term was expanded, it was called "communicative competence". The term "communicative competence" appeared on the basis of the idea of the American linguist N. Chomsky about linguistic (linguistic competence). N. Chomsky and Berwick R. defined linguistic (in the broad sense of the word) competence as "a system of intellectual abilities, a system of knowledge and belief that develops in 
The analysis of the scientific literature concludes that the early childhood and in interaction with many other factors determines ... types of behavior" [7].

In the 1970s D. Hymes introduced the concept of communicative competence (CC) when he argued that to understand first language acquisition, it was necessary to take into account not only how grammatical competence but also the ability to use language appropriately were acquired, thus placing emphasis on sociolinguistic competence among native speakers. According to D. Hymes, the meaning of CC was an internal understanding of the situational relevance of the language. The structure of CC included: grammatical, sociolinguistic, strategic and discursive competence [19]. The theory of D. Hymes was a very important contribution to the field of teaching a second language (foreign). This was the first revolutionary step in the field of language teaching.

The idea of Hymes was taken up by M. Canale and M.Swain in North America [11] and Van Ek in Europe, who applied it to foreign language acquisition and turned it into a fundamental concept in the development of communicative language teaching [15]. M. Canale and M.Swain identified 4 main types of competencies which in interaction with the system of knowledge and skills develop communication (Table II).

TABLE II. COMPONENTS OF COMMUNICATIVE COMPETENCE

\begin{tabular}{|l|l|l|l|}
\hline \multicolumn{9}{|c|}{ Communicative competence } \\
$\begin{array}{l}\text { grammatical } \\
\text { competence: } \\
\text { vocabulary, } \\
\text { phonetics, } \\
\text { spelling, } \\
\text { sematics and } \\
\text { syntax }\end{array}$ & $\begin{array}{l}\text { Sompetence: } \\
\text { correspondence } \\
\text { of statements in } \\
\text { forrn and } \\
\text { meaning in a } \\
\text { particular } \\
\text { situation, } \\
\text { contextual } \\
\text { background }\end{array}$ & $\begin{array}{l}\text { ability to build } \\
\text { holistic, } \\
\text { coherent and } \\
\text { logical } \\
\text { statements in } \\
\text { oral and written } \\
\text { speech }\end{array}$ & $\begin{array}{l}\text { Strategic } \\
\text { competence: } \\
\text { compensation by } \\
\text { special means } \\
\text { inadequate } \\
\text { knowledge of } \\
\text { the lanfuage, } \\
\text { speech and } \\
\text { social of } \\
\text { experience of } \\
\text { communication } \\
\text { in a foreign } \\
\text { language } \\
\text { environment }\end{array}$ \\
\hline
\end{tabular}

In domestic linguodidactics, the term "communicative competence" was introduced into scientific use by M.N. Vyatyutnev [29]. He proposed to understand communicative competence "as a choice and implementation of speech behavior programs depending on a person's ability to navigate in a particular communication environment; the ability to classify situations depending on the topic, tasks, communicative aims before the students' conversation, as well as during the conversation in the process of mutual adaptation".

It should be noted that different scientific schools determine the components of communicative competence in different ways. The definition of communicative competence proposed by V.V.Safonova as a combination of language, speech, and sociocultural components is firmly entrenched in the domestic methodology and existing in Federal Programs of Foreign Languages. This definition successfully combines existing domestic and European attempts to determine the full meaning of this competence [27]. opinion of most researchers agrees on the multicomponent nature of this type of competency. The main components of a foreign language professionally-oriented communicative competence include linguistic, sociolinguistic, intercultural, compensatory, strategic and social competencies. receptive lexical and grammatical skills, speech and language skills in all types of speech activity, knowledge of the rules for using the language.

Sociolinguistic competence means the ability to select and transform linguistic forms depending on the nature of communication.

Intercultural competence provides for the willingness and ability to conduct a dialogue of cultures, knowledge of the social and cultural context in which the language operates.

Compensatory competence means the development of skills to get out of a difficult situation (with a lack of vocabulary) through the use of other means, for example, synonyms, antonyms, periphrase, etc.

Strategic competence involves mastering a system of knowledge about how a language can be learned and used.

Social competence provides for the presence of personally significant experience and the ability to make communication with other people, the ability to navigate in a communication situation, the skill of productive partnership in a communication environment.

Despite the different approaches to the definition and understanding of communicative competence, it has a very clear structure, the main components of which are competencies that characterize it from different points of view and give an overall, quite complete description of the concept of "foreign language communicative competence".

We have mentioned above that intercultural competence is one of the main components of communicative competence. The relevance of the study of the interaction of cultures in the field of international cooperation, the characteristics of national business cultures, the nature of the cultural barriers that arise as well as communication in the field of professional activity is confirmed by a large number of studies and publications on this topic by both foreign and domestic.

Intercultural competence is developed in the learning process. Taking into considering that the interpenetration of cultures is manifested primarily in communication, it is logical that intercultural competence becomes primarily one of the main components of foreign-language communicative competence, that is, an integral part of the process of mastering a foreign language. I. Pluzhnik believes that intercultural communication presupposes "adequate mutual understanding of two participants belonging to different national cultures in a communicative act" [25].

There are several concepts related to the intercultural competence of an individual, namely: "intercultural understanding", "intercultural (background) knowledge", "intercultural awareness", "intercultural flair". Since they are
Linguistic competence includes automated expressive and 
all similar in content but not identical, it becomes necessary to consider each of them separately.

Intercultural understanding is based on a person's ability to understand, correctly interpret and correctly respond to people's behavior or situations, which are based on prerequisites for misunderstandings because of cultural differences. Studying the characteristic features of national cultures in foreign language classes at a university should provide students with relevant knowledge and skills with which to achieve understanding in intercultural communication.

Intercultural (background) knowledge plays a crucial role in intercultural understanding. Moreover, without intercultural understanding existence of intercultural knowledge is impossible at all. Intercultural knowledge provides students with general cultural characteristics, values, beliefs and behavior of representatives of a particular national culture.

Intercultural awareness is developed on the basis of intercultural knowledge as the student begins to realize and evaluate foreign culture on a personal level. This process is accompanied by changes in the social behavior of the student, manifested more in his openness, adaptability to communication.

Intercultural flair is the ability to interpret situations, the behavior of representatives of other cultures, as well as the ability to respond to them correctly. An adequate reaction is possible if a person ceases to interpret events only on the basis of his own culturally determined perception, that is, for example, to define a phenomenon as good or bad, right or wrong, based on the norms and rules of his own national culture.

In our opinion intercultural competence means the ability of an individual to cooperate productively with representatives of other cultures; this concept is broader than the concept of "intercultural understanding", "intercultural knowledge", "intercultural awareness", "intercultural flair".

According to N. M. Gubina, intercultural competence is the ability to perceive, understand, interpret the phenomena of foreign culture and the ability to compare, find differences and common features with the native mentality and national traditions, critically comprehend them and build into their own picture of the world. At the same time, not only a general readiness for communication and interaction is necessary, but also a special cultural consciousness, realistic self-esteem, empathy of a foreign individual, tolerance, emotional stability, self-confidence, the ability to overcome contradictions are required [17].

As noted by I. L. Pluzhnik, a different perspective on the understanding and interpretation of intercultural competence is due to the need to consider it from the standpoint of professional activities of specialists. According to this view of the meaning of the phenomenon, the concept of intercultural competence "is a functional ability to understand the views and opinions of representatives of another culture, to adjust one's own behavior, to overcome conflicts in the communication process, to recognize the right to existence of various values, norms of behavior. Such understanding is becoming most in demand for a modern specialist. It creates the basis for professional mobility, preparation for rapidly changing living conditions, introduces a specialist to the standards of world achievements, increases the possibilities of professional self-realization based on communication and tolerance" [25].

It is worth noting that intercultural professional interaction presupposes a high level of proficiency in both a complex of professional knowledge and a foreign language. It also implies the ability to adequately interpret and accept the sociocultural characteristics of communication partners in solving practical professional problems. To achieve this result, integrated teaching of the language and the characteristics of the cultural environment of its native speakers is required.

Different cultures and cultural traditions are very diverse, so barriers, obstacles and difficulties arise in communication. Mutual cultural differences manifest themselves in different areas, such as behavior, etiquette, norms, values, enduring expressions and non-verbal communication.

In the business sphere, mutual cultural differences arise in areas such as management style, corporate culture, marketing, intercultural negotiations. Views and values are very different from culture to culture, and in order to succeed, you need to know the rules of negotiating internationally. That is, any kind of international business relations implies intercultural communication and an understanding of the culture of the country with which a deal is made or negotiations are just being conducted. Compliance with the rules of such negotiations leads to the desired final result and greatly affects the success of the business.

In connection with all of the above, the making out of a methodology for comparing business cultures of different countries in the process of training specialists in the business sphere is of particular importance.

\section{CONCLUSIONS}

The development of foreign language intercultural competence in teaching future business specialists of nonlinguistic universities is a necessary condition for the preparation of modern bachelors / specialists. Culture teaching and language teaching are inseparable in this context and culture is always embedded, integrated into language learning process.

Intercultural communicative competence is a competence of a special nature. It is not identical to communicative competence of a native speaker and can only be found in intercultural communicant — linguistic identity, to know through the study of languages of different cultures and especially their (cultures) interact. Intercultural competence is an ability that allows a linguistic personality to transcend its own culture and acquire the qualities of a mediator of cultures without losing its own cultural identity. Intercultural competence has a complex structure and correlates with foreign language communicative competence in a very complex way. 
[12] A. Cekaite, "What Makes a Child a Good Language Learner? Interactional Competence, Identity, and Immersion in a Swedish Classroom", Annual Review of Applied Linguistics, vol. 37, 2017, pp. 45-61. doi:10.1017/S0267190517000046.

[13] S. Chiper, "Intercultural communication in business schools: what we can teach and how we can evaluate", Procedia Economics and Finance, vol. 20, 2015, pp. $119-124$.

[14] R. Draeger, "International Faculty in Chinese Universities' Foreign Language Teaching Preferences", Journal of Intercultural Communication Research, vol. 48(4), 2019, pp. 384-399.

[15] J.A. van Ek, (with contributions by L.G. Alexander), The Threshold Level for Modern Language Learning in Schools, 1977.

[16] J. Glover, H. Friedman, "Transcultural competence: Navigating cultural differences in the global community", Washington, DC: American Psychological Association, 2015.

[17] N.M. Gubina, The students' crosscultural competence developing in the elective course of Business English (advanced level, The World Economics specialty), 2004, p. 226.

[18] J.K. Hall, "A prosaics of interaction. Culture in Second Language Teaching and Learning", Cambrige: Cambrige University Press, 2003, pp.137-151.

[19] D. Hymes, On Communicative Competence. Sociolinguistics, 1972, pp. 269-293.

[20] G. Hofstede, "Cultures and Organization: Software of the mind", Maidenhead, 1991.

[21] H. Kelly-Holmes, "Multilingualism and Technology: A Review of Developments in Digital Communication from Monolingualism to Idiolingualism", Annual Review of Applied Linguistics, vol. 39, 2019 , pp. 24-39, doi:10.1017/S0267190519000102.

[22] J. Kroll, P. Dussias, M. Bajo, "Language Use Across International Contexts: Shaping the Minds of L2 Speakers", Annual Review of Applied Linguistics, vol. 38, 2018, pp. 60-79, doi:10.1017/S0267190518000119.

[23] Mahara ePort System https://mahara.org/

[24] J.G. Oetzel, "Effective Intercultural Workgroup Communication Theory", The International Encyclopedia of Intercultural Communication, 2017, pp. 1-5, doi:10.1002/9781118783665.ieicc0025.

[25] I.L. Pluzhnik, The Humanities students' cross-cultural communicative competence developing within their university training course, 2003, p. 326.

[26] A. Rosyidi, O. Purwati, "Revealing Intercultural Communicative Competence in an EFL High School Textbook. Advances in Social Science", Education and Humanities Research (ASSEHR), vol. 108, 2017, pp. 65-69.

[27] V.V. Safonova, Communicative competence: modern approaches to multilevel description for methodological purposes, 2004.

[28] C. Shahlaei, M. Rangraz, D. Stenmark, "Transformation of competence - the effects of digitalization on communicators work", Proceedings of the 25th European Conference on Information Systems (ECIS), Guimarães, Portugal, June 5-10, 2017, ISBN: 978-989-20-7655-3.

[29] M.N. Vyatyutnev, "Traditions and innovations in the modern methodology of teaching the Russian language and literature", Reports of the Soviet delegation at the MAPRYAL congress, 1986, pp. 79-84.

[30] J. Turizo, P. Gómez, "Intercultural communication and ELT: A classroom experience", HOW, vol. 13(1), 2006, pp. 139-152.

[31] A. Watanabe, "Engaging in an interactional routine in an EFL classroom: The development of L2 interactional competence over time", Novitas-Royal, vol. 10, 2016, pp. 48-70.

[32] H.G. Widdowson, "Aspects of language teaching", Oxford: OxfordUniversity Press, Knapp K. Intercultural Communication in EESE, http:webdoc.sub.gwdg.de/edoc/ia/eese/strategy/knapp/4_st.html.

[33] T.R. Williams, "Exploring the impact of study abroad on students' intercultural communication skills: Adaptability and sensitivity", Journal of Studies in International Education, vol. 9, 2005, pp. 356-371.
[10] M. Canale, From communicative competence to communicative
language pedagogy. In Language and Communication, 2014

11] M. Canale, M. Swain, "Theoretical bases of communicative approaches to second language teaching and testing", Applied Linguistics, vol. 1, 1980, pp. 1-47. 
[34] J. Wilson, C. Ward, R. Fischer, "Beyond culture learning theory: What can personality tell us about cultural competence?", Journal of Cross-
Cultural Psychology, vol. 44, 2013, pp. 900-927. 